$$
\begin{gathered}
\text { DEPARTMENT OF THE INTERIOR } \\
\text { UNITED STATES GEOLOGICAL SURVEY }
\end{gathered}
$$

\title{
GEOLOGY AND COAL DEPOSITS OF THE TERRE HAUTE AND DENNISON QUADRANGLES, VIGO COUNTY, INDIANA \\ By \\ S. A. Friedman
}

COAL INVESTIGATIONS

MAP C - 44

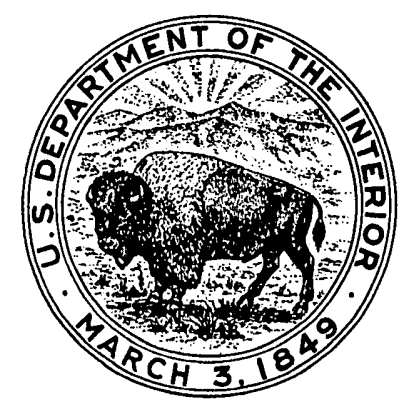

